\title{
Michael E.H. Boeckstyns, Martin Richter: Fracture of the hand and carpus-FESSH 2018 instructional course book
}

\section{Thieme Verlag New York, Stuttgart, Delhi, Rio de Janeiro, 2018, 290 pp, 629 figs., Hardcover, EUR(D) 129,99 EUR(A) 133,70 CHF 149,00, ISBN: 978-3-13-241720-5}

\author{
Alain G. Graftiaux ${ }^{1}$ - Pierre H. Kehr ${ }^{1}$
}

Received: 27 February 2019 / Accepted: 20 July 2019 / Published online: 29 July 2019

(c) Springer-Verlag France SAS, part of Springer Nature 2019

This book corresponds to the teaching book of FESSH 2018. It includes all topics related to fractures of the hand and carp. Each chapter is written by a reference author in his/her subject. It is not a book of consensus but rather a book trying to be as exhaustive as possible even if the various authors tend to privilege their habits.

The book is divided into several parts: general considerations about indications, different materials, different types of patients. A second part describes the fractures of phalanges, then metacarpals and finally carp. This book will provide a good general idea but will require to be supplemented by other readings to deepen a particular point.

\section{Compliance with ethical standards}

Conflict of interest The authors declare that they have no competing interests.

Publisher's Note Springer Nature remains neutral with regard to jurisdictional claims in published maps and institutional affiliations.
Pierre H. Kehr

pierre.kehr@gmail.com

1 Strasbourg, France 